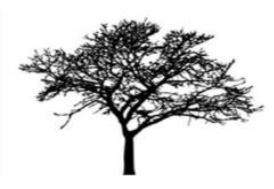

\author{
AVRASYA Uluslararası Araştırmalar Dergisi \\ Cilt : 8 Sayı : 23 Sayfa: 75 - 93 Eylül 2020 Türkiye \\ Araştırma Makalesi
}

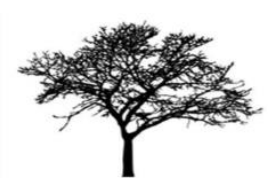

\title{
YERYÜZÜNÜN DIŞLANMIŞLARI: JEAN-MARIE GUSTAVE LE CLEZIO'NUN ALTIN BALIK ADLI ROMANINDA MARJINAL KARAKTERLER
}

Doç. Dr. Şevket KADIOĞLU*

\begin{abstract}
Öz
2008 yılında Nobel Edebiyat Ödülü ile taçlandırılan Jean-Marie Gustave Le Clézio, çağdaş Fransız yazınının kayıp uygarlıklara ve üçüncü dünya ülkelerine duyduğu ilgi ve sempati ile dikkat çeken yazarlarından biridir. Köken olarak Maurice Adası'nda büyük topraklara sahip bir aileden gelen ama Fransa doğumlu olan Le Clézio, her zaman iki kökenli olduğunun bilincinde olmuş, Metropol ve Sömürge arasında kendisini parçalanmış hissetmesine karşın her zaman sömürgecilik karşıtı tutumunu romanlarında yansıtmıştır. Le Clézio'nun bir çok romanında yer alan marjinal karakterler de bir yandan onun insanlığa duyduğu sempatiyi tanıtlarken diğer yandan sömürgecilik karşıtı tutumunun taşıyıcıları olarak dikkat çekiyorlar.

Biz bu çalışmada Le Clézio'nun Altın Balık adlı romanındaki marjinal karakterler üzerinden iletmeye çalıştığı insanlık sevgisine, sömürgecilik karşıtığına, Batı Dünyası (Amerika dahil ) eleştirisine odaklanacağız. Büyük yoksunluklar, kötü koşullar, aşağılanmalar, tacizler, karşılaştıkları insanlık dışı davranışların yol açtığı ruhsal çöküntüler içinde bu marjinallerin ortaya koydukları ayakta kalma savaşımına dikkat çekeceğiz. Çoğu zenci, Arap, ve çingenelerden oluşan marjinal karakterler yaşadıkları olumsuzluklarla dünyadaki kötülükleri serimlemeye olanak tanırlarken, yaşamı yalın yanıyla içselleştirmeleriyle de batının hırslı, bireyci, bencil ve sömürgen insanı ile karşıtlık oluşturmaktadırlar. Çalışmamızda bu karşıtlığı da vurgulamaya çalışacağız. Çalışmamızı hazırlarken Fanon, Césaire Said gibi düşünürlerin söylemleri ile marjinallik üzerine yapılmış sosyolojik inceleme ve çalışmaların bize ışık tutacağını umuyoruz.
\end{abstract}

Anahtar Kelimeler: Le Clézio, marjinal, Batı Dünyası, sömürü, yoksulluk.

\section{THE EARTH'S OUTCASTS : MARGINAL CHARACTERS IN JEAN-MARIE GUSTAVE LE CLEZIO'S FISH OF GOLD ABSTRACT}

Crowned with the Nobel Prize for Literature in 2008, Jean-Marie Gustave Le Clézio is, in contemporary French literature, one of the writers who draws attention with his interest and sympathy for lost civilizations and Third World countries. Coming originally from a family with large land in Mauritius but born in France, Le Clézio has always been aware of his two origins, and although he feels torn between the colony and the metropolis and he reveals his anticolonial attitude in his novels. While his marginal characters in his show, on the one hand, his sympathy for the whole humanity, they, on the other hand, attract our attention as the critics of his anti-colonial attitude.

In this work, we will try to focus on the love for humanity, anti-colonialism and the criticism of the Western world (including America) that Le Clézio undertakes to reflect through marginal characters in his novels. We will draw our attention to the struggles of surviving by Le Clézio's marginal characters as a result of the great deprivations, bad conditions, humiliations, abuses, harassments and in the spiritual depressions caused by inhumane treatment. We hope

\footnotetext{
- Pamukkale Üniversitesi, Fransız Dili ve Edebiyatı Bölümü, kadioglu_s@hotmail.com. Orcıd ID: 0000-0002-3040-6250
} 
that the writings of certain theorists such as Aimé Césaire, Frantz Fanon and Edward Said and certain sociological works done on marginality will guide us while preparing our work.

Keywords: Le Clézio, marginal, Western World, exploitation, poverty.

\section{1- MARJINAL VE MARJINALLIK:}

Marjinal ve marjinallik kavramlarını toplumsal bir bağlama oturtarak tanımlamak istediğimizde, "toplumu karmaşık ve sürekli değişken bir kuvvetler etkileşimi olarak" (Collins, Makowsky 2014: 110) gören Max Weber'in toplumsal tabakalaşma kuramı akla geliyor ister istemez. Siyasal, ekonomik ve kültürel tabakalaşma olmak üzere üç tip tabakalamadan söz eden "Weber'in ana savı, ekonomik alanda, siyasi mücadelede veya kültürel alanda ortak durum ve çıkarları paylaşan insanların birlikte hareket edip arkadaşlık kurmaya ve diğer herkesi bu birlikten dışlamaya eğilimli oldukları yönündedir" (Collins, Makowsky: 110 ). Weber sosyolojisinde "ekonomik, siyasi ve kültürel ürünler birbirleriyle değiş tokuş edilebilir ve Weber bu üç hiyerarşinin toplumsal sükunet dönemlerinde birleşme eğiliminde olduklarını varsayar" (Collins, Makowsky: 113). Bu birleşme eğilimi uyarınca zengin olan aynı zamanda güçlü ve kültürlü olmaya çabalar, kültürlü olan güç ve zenginlik ister, güçlü olan ise bu gücünü zenginlik ve kültürle pekiştirmeye çalışır. (Collins, Makowsky: 113) "Fakat ekonomi, siyaset ve kültür sahaları içindeki rekabet belli aralıklarla sınıflar, güç odakları ve statü gruplarından oluşan kompozisyonu altüst eder ve biz üç hiyerarşinin tekrar tekrar pekiştiğini ve kendini yeniden organize ettiğini görürüz" (Collins, Makowsky: 113). Bu biçimde sürüp giden bir savaş platformu olan tarihte, sosyal tabakalaşma içinde değişik ve kendine özgü grupların ortaya çıktığına tanık olunur. Marjinal gruplar adı verilen adı verilen olguyu da bu sürecin bir sonucu olarak düşünmek gerek. Toplumsal bir tabakalaşmanın ürünü olduğu düşünülen "marjinal"in sözcük içeriği nedir? Le Petit Robert sözlüğünün tanımına göre marjinal "toplum dışında yaşayan kişi”" (1983: 1154) anlamına gelmektedir. Marjinalite ya da marjinallik ise marjinal sözcüğünden hareketle marjinal olma hali, marjinal kişinin içinde bulunduğu durum olarak tanımlanabilir. Marjinal kişinin toplum dışında yaşaması toplumsal normları yadsıması ve topluma uyum sağlayamaması ile ilgili olabileceği gibi, toplumsal olarak dışlanmış olmasıyla da ilgili olabilir. Bu durumda marjinal olma durumunun iki yönü ile karşı karşıya kalırız. Kişi ya marjinal olma durumunu isteyerek seçmektedir ya da buna istemeden maruz kalmaktadır. Marjinali tanımlarken baş vurulan "toplum dışı" ifadesi yanılgıya neden olmaktadır zira hangi durumda olursa olsun marjinali yaratan toplumdur, toplumun ürünüdür ve toplum dışında tutulması olanaksızdır.

Marjinalliği genelde merkezden uzak kenar mahallelerde, merkezin uzağına itilmiş yerleşim alanlarında yaşayan grupların durumu çerçevesinde ele alan sosyolojinin bu grupların yoksulluğuna vurgu yapan bir marjinallik yaklaşımını sosyal marjinallik düzleminde tartışmayı daha sonraya bırakarak, marjinalliğin Liliane Rioux'nun da (Rioux 1998: 635) vurguladığı üzere iki boyutta ortaya çıktığını söyleyebiliriz. Bunlardan birincisi marjinalliği merkez-çevre ikiliği (binôme) üzerine oturtan ve marjın merkeze uzaklığının yarattığı farklııı, ayrışma, uyumsuzluk, çatışma ve diğer sonuçları sürece katan ve konuyu bu çerçevede tartışan, eylemde bulunan ve olası çözüm önerileri getiren bir yaklaşımdır. İkincisi ise marjinalliği normallik-

\footnotetext{
${ }^{1}$ Kaynakça 'da Fransızca olarak yer alan kitaplardan ve web sitelerinden aktarılan alıntıların çevirileri bizim tarafımızdan yapılmıştır.
} 
anormallik ya da normallik ve normal olandan sapma, normun dışına çıkma veya taşma düzlemi üzerine oturtan ve olguyu bu çerçevede tanılamaya çalışan, yönsemelerini incelemeyi amaçlayan, toplumsal görüngülerini çözümlemeye çabalayan, doğurduğu toplumsal sorunları irdeleyip uyumsuz ya da normalden uzak marjinal grupların topluma uyumu için öneriler sunmaya çalışan bir yaklaşımdır. Ama birincisinde söz konusu uzaklığın ölçülebilirliği, nicel ya da nitel karakteri göz ardı edilerek, ikincisinde de normallik olarak nitelenen ya da sapma, sapkınlık olarak tanımlanan şeyin karakteri dikkate alınmadan, çoğunlukla takınılan tavır, bunların üzerinde herhangi bir sorgulama yapmaksızın marjinallerin, suçlu olduklarına karar verilip günah keçisi olarak damgalanmaları, uygulamaya konulan strateji ise yine onların normale döndürülmeye, çizgiye sokulmaya çalışılmalarıdır. Burada elbette, yönetici güçlerin, devletin ve siyasetin yapılandırıcı politikaları yanında, toplumu ya da merkez toplumu oluşturan bireylerin önyargılarının da büyük payı vardır. Siyaset, devlet ve maalesef ticaret, marjinalleri, marjinalliği doğuran toplumsal koşulları ortadan kaldırmak ve ne yazık ki kimi ülkelerde toplumsal bir kara deliğe dönüşen marjinali/ marjinalliği yaratan koşul, uygulama ve insanlık dışı işleyişlere son vermek yerine, bütün bunları görmezden gelerek, yoğunlukla marjinalleri toplumla bütünleştirmeye çalışmaları bu toplumsal "sorun"u biçimlendiren güç ve egemenlik öbeklerinin siyaseti yapılandırıcı etkisinin bir sonucu olarak ortaya çıkıyor. Örneğin uyuşturucu pazarlaması için marjinalleri kullanan uyuşturucu tüccarı küresel güçler belki de bu marjinalliği doğuran toplumsal nedenlerin çözümüne yanaşmayacaklardır.

Aslında bütünüyle toplumsal bir çerçeve içinde anlam bulan ve toplumsal neden, toplumsal yasıma ve yine toplumsal sonuçlarıyla yaşamın her alanında karşılaşılan, yüzleşilen, doğurduğu sonuçlar nedeniyle etkileyen, ayrıksın durumundan dolayı yadırganan, yer yer kınanan, tepki uyandıran ve de toplumun onayladığı bir çerçeve içine sokulmaya çalışılan marjinal ve marjinallik, uzman bilim insanı ve sosyologların değerlendirmelerine göre üç ana öbekte incelebilir: Toplumsal, marjinallik, uzamsal marjinallik ve kimliksel marjinallik. (Yves Barel 1982: 139) Bunların dışında belki kimliksel marjinalliğin alt öbeği olarak incelenebilecek olan kültürel marjinallikten ve psikolojik marjinallikten de söz edilebilir. Toplumsal marjinallik kavramına kaynaklık eden marjinal insan kavramı ilk kez Park tarafından, göçmen bireylerin bir yandan kendi öz toplum ve kültürüne diğer yandan da onları kabul eden ülkenin toplum ve kültürüne dahil olmayı dile getiren çifte aidiyet durumu ya da iki arada kalmışlık sorunsalı çerçevesinde ortaya atılıyor. Cuche'nin Park'tan aktardığı tanıma göre "marjinal insan, bütünleşmesi ve kaynaşması hiçbir zaman bütünüyle gerçekleşmeyen iki toplum, iki kültürün "marj"ında kalmış bireydir" (Cuche 2009: 1331).

$\mathrm{Bu}$ marjinallik durumu, sonuç olarak marjinal insan için iki kültürden tam anlamıyla ne biri ne de diğeriyle özdeşleşme durumudur. Marjinal "insan, kaderin sadece farklı değil yanı zamanda çatışkın olan ve ruhunda iki dünyanın uyumsuzluğunu ve uyumunu, çekiciliğini ve iticiliğini bir arada yansıtan, iki toplum, iki kültür içinde yaşamaya mahkum ettiği bireydir. ( Denys Cuche 2009: 13-31)

Dikkat edilirse Robert Park'ın marjinal insan tanımı kültürel ve kimliksel marjinalliğe de dokunmakla birlikte kendi toplumu içinde marjinal olma durumuna değinmemektedir. Bu çerçevede "toplumsal marjinallik, kimi birey veya grupların 
baskın toplumsal normlara uyum sağlayamaması ya da boyun eğilmemesi olarak" (Larousse) tanımlanmaktadır. Toplumda baskın olan normlara göre, gönüllü ya da gönülsüz yaşanan marjinal olma durumu, toplumun belli marjinallik durumlarına karşı tutum ve tepkisine bağlı olarak, gizli ya da görünür olabilen kendine özel alan ve mekanlarını da yaratır. Bu açıdan değerlendirildiğinde toplumsal marjinalliğin, normallik, toplumsal denetim ve sapma/ sapkınlık karşıtığı üzerinden ortaya çıktığı anlaşılır. Çatışkın ve karşıt toplumsal olgu, edim, yapı ve yapılandırmalar toplumsal marjinalliğin çeşitli yönsemelerinin ortaya çıkmasına zemin hazırlayabilir. Bu noktada fiziksel görünüş, etnik farklılı, hatta cinsiyet farklılığı marjinalliğin belirleyicileri olabilmektedir. Arlette Bouloumié'ye göre:

İlk aşamada fiziksel olarak: özürlüler, körler, topallar, kamburlar, solaklar, zihinsel engelliler, yüzyıllara göre marjinalleştirildi veya dışlandı; etnik olarak: bu, belirli ülkelerde veya belirli zamanlarda siyahlar, Yahudiler veya çingeneler için geçerlidir; cinsel olarak; hayat kadınları, fahişeler, eşcinseller. Kadınlar da cinsiyetleri nedeniyle toplumda marjinalleştirilmemişler mi? Son olarak, entelektüel: yaratıcılar, lanetli şairler, akademisyenler, aydınlar, sıklıkla iktidarın hedefi haline geldiler. ${ }^{2}$ (Bouloumié 2003: 12)

$\mathrm{Bu}$ kadar geniş bir yelpazede ortaya çıkan toplumsal marjinallik, zaten marjinalliğin bizzat yaşamın ve varoluşun birçok düzlemiyle dirsek teması içinde olması ve toplumun değişik alanlarıyla ilişkisel yakınlığı nedeniyle de kuşatıcı bir karakter içermektedir. Bu nedenle örneğin biraz sonra değineceğimiz kimliksel marjinallik aynı zamanda toplumsal bir karakter içermektedir.

Kimliksel marjinallik bireyin dışarıdan gözlemlenebilen, ya da yalnızca kendisinin algılayabildiği farklılığı ile ilgilidir. Ama bu farklılık toplum tarafından bir uyumsuzluk olarak algılandığı için bireyi ailesiyle, yakın çevresiyle, toplumla çatışma içine sokabilir. Kişi giderek onlardan uzaklaşır ve kendini soyutlar, kendisini farklı hisseden diğer kişi ya da gruplarla yakınlıklar kurar. Daha çok gençlerin kimlik edinme, kişilik kazanma çabaları çerçevesinde ortaya çıkan bu farklılaşma yordamı kimi zaman da varoluşsal bir boyut kazanarak kişinin tüm yaşamı boyunca sürebilir. Bu durum marjinallik teriminin bütün titreşimleri ile örtüşmese de normal olandan belli bir ayrılmayı, sapmayı imlediği için marjinallik kapsamında değerlendirilebilmektedir. Kimliksel marjinallik, kendi yurdunu terk ederek ya da terk etmek zorunda kalarak bir başka ülkeye sığınan/yerleşen göçmenin yaşadığı kültürel marjinallikle sarmal bir biçimde de ortaya çıkabilir. Bu bağlamda göçmen, hem toplumsal, hem kültürel hem de kimliksel marjinalliği bir arada deneyimler. Durum söz konusu ülkede vatandaşlık almış olan yabancılar ve bir dereceye kadar onların bu ülkede doğup büyümüş olan çocukları için de aynıdır. Göçmen için iki kültür arasında kalmışlık kimlik sorunlarını ve bu marjinallik çerçevesinde ortaya çıkan daha farklı sorunları da doğurur:

Çift yanlılık, bir yandan geniş bir özgürlükler ve fırsatlar alanı sunduğu için marjinal insanda belli bir hayranlığa neden olan, diğer yandan, ona tehlikelerle dolu olarak göründüğü için aynı zamanda bir korku kaynağı olan ve de göçmen çeşitli biçimlerde yabancı düşmanlığına, ırkçılığa ayrımcılığa

\footnotetext{
2 Bouloumié, Arlette, Önsöz; Figures du marginal dans la littérature française et francophone, Presses universitaires de Rennes 2003, s.12
} 
maruz kaldığında ise tiksinti uyandıran bu yeni ülkenin toplumu ve kültürü bakımından da algılanabilir bir durumdur.(Cuché 2009: 13-31)

Bir yandan bu yeni ülkenin kendisine sunduğu fırsatlar nedeniyle hayran olduğu, diğer yandan maruz kaldığı olumsuz durumlar nedeniyle tiksindiği bir ülkenin değerlerini benimseyip benimsememe, bu toplumla bütünleşip bütünleşememe konusunda da bir ikilem yaşayan marjinal kişi kaçınılmaz olarak belirgin bir kimlik bunalımıyla da karşı karşıya gelir. Marjinal kişinin içsel çatışmasını alevlendiren şey de çoğu kere yaptığı kültürel seçim değil ama bu seçim doğrultusunda yaşamını düzenlemeye çalışırken karşılaştığı toplumsal engellerdir. Bu da çeşitli kategorilerde incelenen marjinalliğin çoğu zaman nasıl iç içe geçmiş bir yapı sergilediğini gösterir. Kültürel, kimliksel, toplumsal marjinallik birbirinden beslenir birbirini doğurur. Marjinal kişinin yaşadığı iç çatışmaya, kimlik bunalımına bağlı olarak kimliksel marjinallikle ilişkilendirilen psikolojik marjinallik de Denis Cuche'nin (2009: 13-31) Bastide'den aktardığı gibi düşlenenle karşılaşılanın farklılığının ironisinden başka bir şey değildir.

Merkez ve çevre ikiliğine dayandırılan uzamsal marjinallik ise toplumsal marjinallik ile ilişkili bir biçimde daha çok sosyolojinin ilgilendiği ve özellikle kentlerdeki yoksulluğa bağı olarak, marjinalleştirilmiş yoksul insanların toplandıkları, yaşadıkları kenar mahalle, banliyö ve gettolara gönderme yapar. Marjinal ve marjinallik sözcüklerinin türetildiği marj sözcüğünün kenar, sınır anlamı ile bağlantılı olarak uzamsal marjinalliğin merkezden uzakta olanı, merkezin dışında kalanı ve bununla ilişkili olarak da dışlanmayı ifade ettiği ortaya çıkar. Ancak, merkezden uzaklık, merkezle kenar arasındaki bu mesafe yalnızca uzamsal bir dışarıdalığa değil aynı zamanda bütüncül yapının dışında olmaya da vurgu yapar ve merkezin kültür kodlarının dışında kaldığı için de, çoğu kez merkezinki ile çatışan kendi yaşam biçimini, kendi değerlerini, kendi kültürünü (alt kültür), kendi ideolojisini ve hatta kendi mimarisini yaratır. Merkezden uzaktaki bu tür yerleşim yerlerinin bütünü için geçerli olmamakla birlikte, "kapitalist ekonomilerin eşitsiz gelişmesi ile refah devletlerinin küçülmesi sonucu post-Fordist şehirlerde billurlaşmış toplumsal-mekânsal sürgün ile dışlayıcı kapatma hadiselerinin görüldüğü yeni düzeni tanımlayan" (Wacquant 2011: 12) ileri marjinalliğin yaşandığı yerleşim yerleri, aşırı kutuplaşma, merkeze güvensizlik ve ölçüsüz yoksulluğun etkisiyle giderek yasaların çiğnendiği güvensiz suç merkezlerine dönüşür. "Hem bu mahallelerin sakinleri hem de dışardakiler bu alanları kent cehennemi olarak niteler; buralarda mahrumiyetten, ahlaksızlıktan, kanunsuzluktan, şiddetten geçilmediğini, sadece toplumdan dışlananların burada yaşamaya tahammül edebileceğini söylerler" (Wacquant 2011: 294). İleri marjinalliğin yaşandığı bu yerler içinde yaşayanların birbirine yabancılaştığı güvensiz yerlere dönüşürler:

Artık mahalle olgusu dış dünyanın baskılarına, tehlikelerine karşı bir kalkan görevi görmüyor, ortak kültürün birleştirdiği o tanıdık çevre değil, artık, eskiden sakinlerinin ortak amaçlarla, ortak eylemlerle güvence bulduğu, yüreklendirildiği bir yerdi oysa. Rekabetin, çatışmanın hüküm sürdüğü boş bir uzama döndü şimdi." (Wacquant 2011: 295)

Yoksul işçilerin, göçmenlerin, etnik ve ırksal olarak dışlanmışların, kanunsuz iş yapanların toplandıkları bu uzamlarda marjinalliğin her türü yaşanır. Ama bu yerlere kapatımışların tek derdi hayatta kalmaktır. Hayatta kalmak söz konusu olunca da bunun için her şeyi yapmaya hazırdırlar. Zira kaybedecekleri hiçbir şey yoktur. Ama toplumun kaybedeceği çok şey vardır. "Zira bir toplum reddettiği şeyle tanımlanır" diyen 
Foucault'ya kulak verecek olursak, kendi bütünlüğünün bir parçası olan toplumun bu parçayı dışarıda bırakarak yaşaması da olanaklı görünmemektedir. Eğer marjinallik bir kanserli hücreyse, çözüm o kanserli hücreyi söküp atmak değil, o hücreyi yaratan bünyeyi tedavi etmek olacaktır.

Marjinallik ve uzam konusunda üzerinde durulması gereken bir başka nokta da marjinalleştirilmiş grupların yaşadığı banliyöler, kenar mahalleleri, gettolar dışında, marjinalliğin daha küçük ölçekli uzamlarla kurduğu ilişki ya da bu uzamlarla bağlantısıdır. Bu bağlamda sözü edilen mekân yatay olarak merkezden uzak ya da kopuk olmamakla birlikte dikey olarak merkezin uzağındadır, derinindedir. Ya da merkezin gizli, görülmeyen, görmezden gelinen uzamlarıdır. Merkezin içindeki bir kara delik gibi, hem merkezde hem de merkezden uzaktır. Bir binanın bodrum katıdır, terk edilmiş bir binadır, bir depodur, köprü altıdır, metrolardır, kanalizasyon boşluklarıdır. Merkezin kara delikleridir. Bu açıdan yaklaşıldığında, güvensizliğin, tekinsizliğin, korkunun, polis baskısının, yasa dışıı̆ın, dışlanmışlığın, yoksulluğun egemen olduğu yerlerdir. Yine toplumun ta kendisidir.

\section{2- LE CLEZIO'NUN YAŞAMI KULLANMA KILAVUZU OLMAYAN MARJINALLERI :}

İlk romanı olan Tutanak'tan son romanına kadar, Le Clézio'nun hemen hemen bütün romanlarında en az bir marjinal karakterle karşılaşmak mümkündür. Le Clézio romanlarını dolduran bu marjinal karakterlerin elbette ki yazarın yaşam felsefesi ile dünya ve yaşamla kurduğu ilişki ile yakın bir bağlantısı vardır. Kayıp uygarlıklara duyduğu ilgi, üçüncü dünya ülkelerine karşı beslediği sempati, az gelişmiş ülke insanlarına karşı geliştirdiği duygudaşlık, ezilen, sömürülen kitlelere duyduğu yakınlık, sömürgeci batı uygarlığına karşı takındığı eleştirel tavır, açgözlü kapitalist dünyaya nefreti ve tüketim toplumuna tepkisi ile dikkat çeken Le Clézio, romanlarında yer verdiği marjinal karakterlerle de bir bakıma Modern Batı Dünyası'nın (Amerika dahil) maskesini düşürür. Özdeksel olarak çok gelişmiş olmakla birlikte, her şeyi maddeye indirgediği için insanlık kökleriyle bağlarını koparan ve giderek ileri derecede teknokratik bir tüketim toplumuna dönüşen batı toplumunun yaşadığı bunalımı, içinde bulunduğu çıkmazları romanlarında, özellikle de yarattığı marjinal karakterlerin yaşadıkları, deneyimleri, serüvenleri, kaygıları, korkuları, umutları, düş kırıklıkları üzerinden yansıtmaya çalışan Le Clézio, mutsuzluğun, köleliğin simgesi olan kente karşı mutluluğu ve özgürlüğü simgeleyen doğaya dönüşe, modern tüketim topluluğunun aç gözlülüğüne karşı ilkel toplumların yetingenliğine, modern bilim ve felsefenin ayrıştırıcı epistemolojik karmaşasına karşı mitlerin birleştirici yalınlığına, grekoromen geleneğin insan merkezli yararcı kültürüne karşı uzak doğu felsefesinin doğayla insanı bütünleştirici anlayışına çağrı yapmaktadır. İnsanı da dar kalıplara sokmaktan çekinen Le Clézio romanlarında kahramanlarını çoğunlukla çocuk ya da ergenliğe adım atmak üzere olan gençlerden seçer; "Bu çocuklar çoğunlukla izole yaşam sürdürürler, arkadaşları, evleri yoktur, marjda, günü gününe, rastlantısal olarak, tesadüf onları nereye götürürse o biçimde yaşarlar; insanları izlemekten, doğayı seyretmekten başka bir işleri yoktur." (Onimus 1994: 126) Bu kahramanları bir tür erginleşme yolculuğuna çıkaran yazar, bu yolculuk sırasında yaşadıkları acılı ya da mutlu deneyimlerle dünyayı ve yaşamı olduğu gibi kendilerini de keşfetmelerini sağlar. Bu kendini arayış yolculuğunda kalıplara sığmayan, ellerinde yaşamı kullanma kılavuzu 
bulunmayan marjinal karakterler de yaşamın, dünyanın gizemlerine açılan kapılarını aralar, tabuları sarsar, yasakları sorgulatır, kaçtığımızı karşımıza çıkarır, sakladığımızı önümüze bırakır, yok saydığımız gerçeklerle yüzleşmemizi sağlar, gerçeklerin yalan, yalanların gerçek, normalin anormal, anormalin de olağan olabileceğini gösterirler. Aynamız olur, maskemizi elimize verirler. Her marjinal karakter yaşamın bilinmeyen, karanlık, tehlikeli, sakıncalı ve belki de tekinsiz bölgelerine doğru yolculuğa çıkarır. Dünyanın bütünlüğü içinde gözlerimizin önüne serilmesi bu karakterler sayesinde olanaklı olur. Le Clézio'nun romanlarında kimi marjinal karakterler de doğaüstü güçlere sahiptir, Naja Naja, Jeune Homme Hogan, Besson, bunlardan sadece bir kaçıdır. Bu karakterler aracılığı ile bilinmez bilinir kılınır, görünmez görünür hale gelir. Doğanın dilinden anlayan, evren kitabını okumasını bilen, yaşamın gizemlerini açımlama gücüne sahip, çoğu zaman bilicilik sanatında da usta olan bu marjinal karakterler, Le Clézio romanlarında esrarlı bir atmosfer yaratır, masalsı bir büyü salarlar ortama. Evrenin bir parçası olduğumuzu anlamamızın, evrene katılmamızın, evrenin sırrına tanıklık etmemizin, evrenin her devinimini içimizde duyumsayıp tadına varmamızın, evrenle bütünleşmemizin mucizevi bilgisini verirler. Yüzeysel varlığı sorgulatan, alışıldık olanı alaşağı eden, olağan olanı sorgulatan marjinal karakterlerin yaşama çevirdikleri bakış objektif bir bakıştır. Marjinal karakterlerin çoğunun çocuk olmasının bir tesadüf olmadığını onun romanlarından bir kaçını okuyan herkes anlar. Zira çocuklar ilksel masumiyete yetişkinlerden daha yakındırlar, dünya, yaşam, insanlara ilişkin yargıları kemikleşmemiştir. Yaşanılanlara, dünyaya, çevreye, topluma, insanlara karşı ön yargısızdırlar. Dolayısıyla onları eğip bükmek, çıktıkları dünyayı ve kendini tanıma yolculuğunda onları evriltmek, bilinçlenmelerini, kendilerini keşfetmelerini sağlamak daha kolay olmaktadır. Le Clézio'nun romanlarındaki hırsızlık yapan bir çocuk sadece bir hırsız değildir. "Kölelikten ve toplumsal adaletsizlikten kaçmak için, şiddetin aldatmalarına boyun eğerler; hırsızıı̆ın, çılgınca hız tutkusunun ve maceranın yarattığı heyecanlar Max Sheler'in sözünü ettiği "uygarlığın iç sıkıntısını" ödünler." (Onimus, 1994: 132) Aklını kaçırmış deli birisi sadece deli değildir, bir sağır ve dilsiz sadece sağır ve dilsiz değildir, bir fahişe sadece bir fahişe değildir, bir çingene, bir göçmen, bir serseri ya da toplumun herhangi bir biçimde, herhangi bir nedenle dışladığı biri sadece dışlanmış biri değildir. Bu karakterler yalın bir bezeksel öge olarak yer almaz Le Clézio'nun roman evreninde. Onimus'un belirttiği gibi "bunların sadece varlıkları bile bütün bir toplumu tartışma konusu yapar." (Onimus 1994: 132) Le Clézio'da öteki tarafa geçmek olarak adlandırabileceğimiz bir yordam vardır ve romanlarından birinin adı da Voyage de l'autre Côté (Öteki Tarafa Yolculuk) dir. Öteki tarafa geçmek yordamı onda dünyaya, yaşama alışık olmadığımız taraftan, belki de ters taraftan bakmak anlamına gelir. Dünyayı tersyüz etmek, yaşamı baş aşağı çevirmek, olanı olmamış, olmayanı olmuş olarak görmek, insanları gölge yanlarıyla yüzleştirmek anlamına gelir. Öteki tarafa geçmek, yaşam, dünya, insana ilişkin yaratılan illüzyonu bozmak anlamına gelir. Bu açıdan Le Clézio'nun ilk romanı olan Tutanak'ın baş kişisi Adam Pollo'nun bir anti-kahraman olarak nitelenmesi de ilginçtir." Toplumla, aşkla, mesleki yaşamla ilgisini koparmış" (Boulos 1999: 64) olan Pollo Yeni Roman'ın, Yeni Tiyatro'nun karakterlerini anımsatmakta, "varoluşla ilgili sorgulamaları da Sartre'in ya da Camus'nün kahramanları ile bir yakınlığı olduğu düşüncesini uyandırmaktadır." (Boulos 1999: 64) Bu anti-kahraman peygamberliğe soyunur kumsalda çevresine toplanan kalabalığa vaazlar vermeye çalışır. Bir başkası, adı bir yılanın ile ilişkilendirilen Naja Naja, gerçek uzamdan düşsel umama süzülür" (Boulos 1999: 66) 
yani öte tarafa geçer. Bu biçimde, Le Clézio'nun roman evreninde bir yandan marjinal diğer yandan imgesel ve söylensel karakterlerle hem gerçek, hem düşsel, hem kozmik hem de mitik dünyanın bilgisi, gizi, gizemi ulaştırılır. İster yaşlı olsun isterse genç ya da çocuk Le Clézio'nun kimi marjinal karakterleri bilgeliğin somut örneği olarak karşımıza çıkarlar. Ama elbette bu bilge marjinaller daha çok yaşılıardır ve yaşamının deneyimi ile bu bilgeliğe ulaşmışlardır. Bu bilge marjinaller bir başka öte tarafın çağrısını dile getirirler. Bu öte taraf kuşkusuz iç dünyamızdır. İç dünyamızı, iç dünyamızın zenginliğini gözlerimiz önüne serer, yaşamın "acı bilgisi"ni de verirler. İleriye doğru kaçışın bir çözüm getirmediğinin, asıl "çözümün dünyadaki varoluşun içsel derinliğinde" (Onimus, 1994:101) olduğunun hikmetini/bilincini verirler. Bu da ontolojik anlamda kendini arayışın içsel zenginliğe vurgu yapan en yüksek düzeyde aşamasıdır. Acı bilgiden elde edilen kendini keşfetmenin bilinci kıvandıran tadı.

\section{3-ALTIN BALIKIN MARJINAL KARAKTERLERI:}

Hemen hemen bütün romanları gibi, Le Clézio'nun Altın Balık adlı romanı da "toplumsal bir söylem ve toplumumuzun sorunlarına yaptığı bir çok gönderme" (Boulos 1999: 52) ile dikkat çeker. Romanını bu biçimde, "bir serüvenin anlatısından öte "günümüz toplumunda insanlık durumu üzerine şiirsel bir anlatı" olarak örgüleyen yazar, toplumdan insan manzaralarını yarattığı marjinal karakterler aracılığı ile yansıtır. Marjinalliğin en önemli göstergelerinden biri olan hiçbir yere bağlı olmama, sürekli hareket halinde olma, yer değiştirme, amaçsızca dolaşma etkinliği romanda ana bezek olarak sürekli karşımıza çıkar ve romanın kahramanı Laïla ${ }^{3}$ gibi zorunlu nedenlerle ülkelerini terk ederek daha iyi yaşam koşulları bulmak umuduyla Fransa'ya gelmiş göçmenlerin, oturma belgeleri olmadığı için, polise yakalanmamak amacıyla sık sık yer değiştirmeleriyle de sürekli olarak pekiştirilir. Bu hareket halinde olma durumu kimi zaman, Le Clézio romanlarının belirleyici özelliği olan kaçışlarla sonuçlanır. Bunlar da Boulos'un (Boulos 1999: 116) vurguladığı gibi, yalnızca dramatik eylemlere ve anlatısal izlemlere olanak sağlayan bir yordam olarak değil aynı zamanda, insanı yabancılaştıran, boğan kent imgesinde somutlaşan varoluşsal kapatılmışıktan, kişinin kendi olmasının olanaksız olduğu koşul ve çevreden uzaklaşma istemi olarak da anlam kazanır. Romanda, kendine kurulan tuzaklara yakalanmamak, gerilen ağlara takılmamak için sürekli kaçan Leyla, romana da adını veren metaforik adıyla Altın Balık, hem çok küçükken kaçırılıp ailesinden koparıldığı için, hem de kendisine kurulan ağlardan kurtulmak amacıyla sürekli kaçmak zorunda kaldığından toplumla sağlıklı bir aidiyet bağı kuramadığı için giderek marjinal bir karaktere dönüşür. Zaten başlangıçta adı bile olmayan (Le Clézio 1997: 8) kendisine gece getirildiği için sahibesinin Arapçada gece anlamına Leyla adını verdiği küçük kızın çocukluğundan başlayarak, kaçırılıp satılmasıyla başlayan tuzaklar, onu, içine hapsedip özgürlüğünü elinden almaya çalışan ağlar, kendisini hiçbir yerde güvenlik içinde hissedememesine neden olur. Başta kendini satın alan sahibim ya da büyükanne dediği kadın Lalla Asma'nın oğlu olmak üzere toplumda karşılaştığı birçok kişi onu ağlarına çekmek, ondan yararlanmak isterler. Lalla Asma'nın evinde sokağa çıkma özgürlüğü olmayan Leyla, sokağı yalnızca çamaşırları asmak için çıktığı çatı katından seyredebilir: "Oradan sokağı, komşu evlerin çatılarını, yürüyen insanları, taşıtları ve hatta iki ev arasından

\footnotetext{
${ }^{3}$ Romanın Türkçe çevirisinde Laïla Türkçe' deki söylenişiyle Leyla olarak aktarıldığı için bundan sonra Leyla'yı tercih edeceğiz.
} 
büyük mavi nehri görüyordum." (Le Clézio 1997: 9) Le Clézio, bu romanında Leyla'yı yaşadığı serüvenlerle mutlak bir toplum eleştirisi olarak somutlaşan bir marjinal karakter olarak karşımıza çıkarır. Zira diğer marjinal karakterler de aynı zamanda romanın anlatıcısı olan Leyla ile ilişkileri çerçevesinde, anlatılır, var olurlar. Leyla'nın ilişki içinde olduğu karakterlerin her biri toplumsal bir yaraya dokunur, insanlık durumu ile ilgili bir gerçekliği tartışmaya açar, bir dramı sorgular. Bu nedenle bu çalışma boyunca Leyla'nın yaşadıklarını, başından geçen serüvenleri, acılı deneyimlerini, karşılaştığı onur kırıcı, insanlık dışı davranmaları anlatılamak gerekli olabiliyor. Leyla, henüz ülkesini terk edip, Fransa'da göçmen olarak marjinal konumuna düşmeden önce kendi ülkesinde de marjinaldir. Toplumun dışarıda bıraktığı, sahibesinin oğlunun tacizi ve gelininin uyguladığı şiddet nedeniyle de çevresine karşı güvenini yitirmiş bir karakter olarak Leyla ilk kaçışını sahibesinin ölümünden sonra kendisini bu ölümünden sorumlu tutarlar korkusuyla gerçekleştirir. Ayakları onu sahibesi hastalandığında, doktor aramak için ilk kez sokağa çıktığında tesadüfen gittiği hana götürür. Bu handa prensesler adını verdiği hayat kadınları Leyla'ya sahip çıkar, sarıp sarmalarlar onu:

Cemile Hanım'ın ve prenseslerin kişiliğinde, şimdiye dek mahrum kaldığım her tür sevinç ve sevgiyi bulmuştum. Acıkınca karnımı doyuruyor, uykum gelince uyuyor, nedeni ne olursa dışarı çıkmak istediğimde kimseden izin almaksızın dışarı çıkıyordum...Sanki kızlarıymışım gibi, beni evlat edinmişlerdi ya da daha çok oyuncak bir bebek, küçük bir kız kardeş gibi zaten beni böyle çağırıyorlardı. (Le Clézio 1997: 26)

Burada dikkat çekici olan Laila'nın sevgiyi zengin bir aile olan sahibesinin oğlunun ve gelininin yanında değil de toplumsal olarak alt tabakada değerlendirilen ve ahlaki nedenlerden dolayı yine toplumdan dışlanmış olan kadınların yanında bulmasıdır. "Dünden beri hiçbir şey yememiştim, karnım açtı ve susuzluktan ölecek haldeydim." (Le Clézio 1997: 24) diyen küçük kızın hana ilk geldiğinde, bu kadınlarla tanışmadan önce açlığını bastırmak için bir tezgâhtan kuru üzüm, incir yerken yakalayarak ona şiddet uygulayan satıcıya prenseslerin bozuk para fırlatmaları oldukça simgesel bir tablo çizer. Paraya önem vermeyen prensesler, para için küçük kıza şiddet uygulayan satıcıya bu şiddetin karşıı̆ı̆ını yine parayla vermektedirler. Fırlatma eylemi, birinin değer verdiği şeyi değersizleştirerek, tam anlamıyla marjinal bir davranış oluşturur. Kendi ekonomik gücünün verdiği cesaret ve güçle satıcı sadece karnını doyurmak için tezgâhından bir şeyler alan çocuğa şiddet uygularken, sembolik bir şiddet etmeni olarak ekonomik güce ve paraya belli bir vurgu yapmakta ama fırlatılan bozuk paralar kendi üzerinde fiziksel şiddetin aracı olmaktadır. Le Clézio'nun kaleminden toplumsal adaletsizliğin maskesinin düşürülmesi olarak yorumlanabilecek bu düello, gücü olanın sevgisizliği, katı kalpliliği ile güçsüz olanın sevgisinin, yumuşak kalpliliğinin düellosudur. Aynı zamanda yaşamda parayı amaç haline getirenlerle onu bir araç olarak kullananların düellosudur. Gerek küçük kız Leyla'ya zengin toplumun kendisine saygın bir yer ayırdığı zengin ailenin değil de, toplumdan dışlanmış hayat kadınlarının sahip çıkmasında, gerekse tezgahında yiyecek bir şeyler olan satıcı tarafından değil de yine hayatlarını kazanmak için bedenlerini satmak zorunda kalan kadınlar tarafından doyurulması, Bakthin'nin sözünü ettiği ters yüz olma durumu ile örtüşmektedir. Burada da sanki bacaklar kafa, kafa ise bacak olmuş durumdadır ve toplumun merkez güçlerinin üstlenmesi gereken işlevin merkez dışı güçler tarafından yerine getirildiğini gösteren oldukça anlamlı bir sahnedir. 
Hayat kadınları diğer yandan marjinalliğin önemli bir kesimini oluşturmaktadır. $\mathrm{Bu}$ tür marjinalliği toplumsal marjinalliğin spesifik bir alanı olarak değerlendirmek gerekir. Zira hayat kadınları çoğunlukla toplumsal ahlaki normları benimsemedikleri için değil, zorunlu başka nedenlerden dolayı hayat kadını olmayı seçmiş, ya da buna zorlanmışlardır. Merkezi hegemonyanın tamamen görmezden geldiği ya da canının istediği zaman gördüğü, yok saydığı, toplumsal olarak dışladığı bu kesim Foucault'nun deyimiyle aslında toplumun ta kendisidir. Varlıkları da başlı başına toplumsal bir eleştiridir. Le Clézio'nun amacı da bu kesimi şirin göstermek değil, onları hayat kadınlığı yapmaya zorlayan koşulları yarattığı halde yalnızca bu koşulların kurbanlarını günah keçisi ilan eden toplumun maskesini düşürmek ve onları toplumsal olarak dışlamasına, merkezin dışına itmesine karşın onlardan yaralanan merkezi güçlerin iki yüzlülüğünü göstermektir:

“ Bugün bile hala prenseslerin prenses olmadığına inanmak zor geliyor bana. Onlarla iyi vakit geçiriyordum. Tasasızlardı, hep gülüyorlardı. Dağ köylerinden kaçmışlar ve buraya kadar gelmişlerdi. Etraflarında karınca gibi insan kaynıyordu, fondukun ${ }^{4}$ kapısına kadar kendilerini almaya gelen lüks Amerikan arabalarına binip gidiyorlardı. Bir akşam, anımsıyorum, renkli camlı, yeşil, beyaz, kırmızı ve siyah bayraklar bulunan, siyah uzun bir araba gelmişti. (Le Clézio 1997: 28)

Yukarıda alıntıladığımız satırlar kadının bir meta olarak damgalanmasına işaret etmesinin yanında, onların bu durumundan yararlananların da yine merkezi güçler olduğuna anlamlı bir vurgu yapmaktadır. Merkezi hegemonya ile dışarıda bırakılanlar, gözden düşmüş olanlar, damgalananlar arasındaki bu paradoksal ve aynı zamanda ironik ilişki aynı zamanda bazı güç odaklarının bu anomaliden beslendiklerini de açık bir biçimde ortaya koymaktadır. Ne yazık ki bu noktada kadının bedeninin meta haline getirilmesinden faydalanan erkekler damgalanmamakla oysa kadınlar damgalanabilmektedir. Bu ayrımcılık da onları daha da marjinalleştirmekte ve "içinde yaşamadıkları" toplumla aralarındaki mesafeyi daha da açmaktadır. Vurgulamak gerekir ki seks işçiliği her zaman istenerek başvurulan bir yol değildir, çoğu kadın için bu son çaredir. Bu bakımdan romandaki Houriya ${ }^{5}$ adlı genç kadın ilginç bir karakterdir. Huriye kendisini zorla kaçıran kocasının ona uyguladığı şiddetten kaçmış ve bu yolla hayatta kalmaya çalışmaktadır: "Kendisini zorla kaçıran ve sonra da sürekli döven Tangalı zengin bir adamla evlenmişti. Bir gün bohçasını hazırlayıp evden kaçmıştı." (Le Clézio 1997: 31) Bu bağlamda kadın damgalanırken göz önüne alınan ölçüt ahlak normları olmaktayken erkeğin ahlak normları açısından yaşam biçimi pek az sorgulanmakta bu da kadının toplumun gözünde itibarsızlaştırımış durumunun eril zihniyet ve güçler tarafından yapılandırılıp, pekiştirildiğini gözler önüne sermektedir. Bu noktada sözü edilen damga, Goffman'ın (Goffman 2014: 33) belirttiği, bedensel bozukluk, zayıf irade, baskıya müstahak ya da doğal olmayan tutkular ve son olarak da ırk, ulus, din gibi etnolojik damga türlerinden hiç biri içinde değerlendirilmemiş olsa da Goffman'ın eserini bütün olarak ele aldığımızda, sonuçta kurbanını "itibarsızlaştıran" (Goffman 2014: 32) ahlaksal bir damga olduğu anlaşılır. Ahlaksal olarak damgalanmış

\footnotetext{
${ }^{4}$ Vikipedi'nin tanımına göre, funduk ya da fonduk ağırlıkı olarak Orta Doğu, İtalya ve Mağrip'te bulunan bir çeşit otel ve malların saklandığı depo, han anlamına gelmektedir.

${ }^{5}$ Romanın Türkçe çevirisinde Houriya Türkçe' deki söylenişiyle Huriye olarak aktarıldığı için bundan sonra Huriye'yi tercih edeceğiz.
} 
olan birinin günlük yaşamda durumu oldukça zordur, bu tür kişiler, daha doğrusu kadınlar, kendileri gibi damgalanmış olanların içinde ya da müşterilerinin yanında daha rahat davranabildikleri halde toplum içinde oldukça zor durumlara düşebilmektedirler. Goffman'ın Rolph'tan alıntıladığı şu tümceler bu açıdan oldukça anlamlı görünmektedir:

Doren Mayfair'den [Londra'nın bir fahişe mahallesi] bir kız anlatıyor) Mahkemeye çıkmak, işin [ fahişe olmanın] en kötü kısmıdır. O kapıdan içeri girersin ve herkes seni bekliyordur ve sana bakıyordur. Kafamı yere eğerim ve iki tarafa da hiç bakmam. Ardından o korkunç kelimeleri söylerler: "Sıradan bir fahişe olarak..."Sen de mahkemenin izleyici kısmında kimin seni izlediğini bilmeksizin kendini berbat hissedersin. "Suçluyum" dersin ve oradan mümkün olduğunca çabuk çıkarsın (Goffman 2014:128)

Diğer marjinal karakterleri olduğu gibi, hayat kadınlarının gerçekliğini de, bu durumu doğuran toplumsal neden ve koşullardan bağımsız ve yalıtık bir biçimde ele almaktan kaçınan Le Clézio, bu karakterlerin yaşadıkları hiçleşme, yabancılaşma, itibarsızlaşma süreci içerisinde onları bir bilinçlenmeye, bir uyanışa doğru yolculuğa çıkarır. Ne yazık bu tür karakterlerin buldukları işler hep eğreti, güvencesi olmayan işleridir ve sürekli olarak ya birilerinden ya da polisten kaçtıkları için de sürekli ve düzenli bir iş bulamamaktadırlar. Yabancı bir ülkeye kaçak olarak gelmiş olanlar da, oturma izinleri olmadığı için ya gelip geçici, ya da yasal olmayan işlerde çalışmaktadırlar. Küresel bir göçmen sorunu olarak karşılaşılan bu durum başka toplumsal sorunları da besleyip doğurmaktadır. Fas'ta kocasının şiddetinden kaçıp başka bir ülkeye gitmek için para biriktirmek amacıyla, bedenini satan ve başka işlerde de çalışan Huriye'nin Fransa'ya giderken Laïla'yı da yanına alması aslında, toplumsal olarak itibarsızlaştırılmış olsalar da insansal değerlerle donatılmış olduklarının gösterir. Le Clézio romanlarında çoğu marjinal karaktere, toplumun, doğanın, yaratılışın, yazgının onlardan esirgediklerini ödünleyici bir özellik, insansal bir soyluluk, bir ruh yüceliği, bir gönül zenginliği, bir bilgelik atfeder. Huriye'de gece gündüz çalışarak kazandığı parayla Leyla'nın da yol parasını karşılayacak kadar gönlü zengin birisidir. "Ne zaman gidiyoruz?" diye sordum. Cevap vermedi, ama ellerimle ağladığını anladım ya da sessizce gülüyordu...Çok yakında. Malaga gemisinde iki kişilik yer açılır açılmaz." (Le Clézio 1997: 64)

Le Clézio'nun karakterlerinin en göze çarpan özelliklerinden biri de özgürlüklerine olan düşkünlükleridir. Onlara göre, yaşamda, dünyada, toplumsal çevrede hiçbir konum ve statü özgürlükten üstün değildir. Onlar aç, susuz kalmayı özgür olmamaya yeğlerler. Toplumun görmezden geldiği, düzenli bir işi, evi, ailesi olmayan ve dolayısıyla kaybedecek bir şeyleri olmayan marjinal karakterlerin tutundukları tek değer özgürlükleridir. Altın Balık'ta Leyla'nın ve diğer bir çok roman kişilerinin özgürlüklerine karşı bir tehdit hisseder hissetmez düşündükleri ilk şey bulundukları yerden uzaklaşmak, kaçmaktır. Leyla'nın gerçekleştirdiği sürekli yinelenen bu kaçışların örgülediği bu romanı Le Clézio'nun başka bir eseri olan Le Livre des Fuites/Kaçışların Kitabı'nın bir başka versiyonu olarak da okumak olasıdır. Le Clézio'da sadece işlevsel akılla kurulan, tüketilen bu dünyayı unutturan bütün kaçışların iyi olduğunu belirten Onimus'un (Onimus 1994:152) yorumuyla her şeyin en üst düzeyde bir verim elde etmek için düzenlendiği ve insanın, diğer insanların arzularının, hırslarının, bencilliklerinin tensel duygularının aleti haline getirildiği köleleştirici bir dünyadan kaçış, bir özgürlük arayışıdır. Bu özgürlük arayışının, Denys Cuche'nin 
marjinal olma durumu ile ilişkilendirdiği özgürlükle bir ilgisi bulunmamaktadır. Cuche'ye göre, "kültürel olarak yabancılaşmış olmanın ötesinde, kültürel marjinaller, gerçeklikle oluşturdukları kopukluk sayesinde, yaratıcılıklarını tetikleyen geniş bir özgürlük ve hareket alanı bulurlar." (Cuche 2009: 13-31) Ama ne yazık ki kendilerinin olmayan bir ülkede hem göçmenliği hem de marjinalliği deneyimlemek zorunda olanların Cuche'nin sözünü ettiği özgürlüğü elde etmeleri zor olduğu gibi, kişisel özgürlükleri de sürekli tehdit altındadır.

Le Clézio'nun Altın Balık adlı romanında marjinal olarak değerlendirdiğimiz karakterler, genellikle eski Fransız sömürgelerinden çeşitli nedenlerle gelerek Fransa'da şansını deneyen, yaşamda kalma savaşımı veren Arap ve zencilerden oluşmaktadır. Bunların dışında bir de Juanico adlı bir çingene çocuk bulunmaktadır. Böyle olunca da marjinallik, kimlik, dil, kültür, aidiyet gibi olgularla iç içe geçmiş gibi görünse de le Clézio'nun marjinal karakterleri için asıl sorun, ayakta kalma, yaşama, yaşamını sürdürme sorunudur. Çünkü başta Leyla ve Huriye olmak üzere, romanda bir çok marjinal karakterlerin hemen hemen hiçbirinin oturma izni belgesi bulunmamakta, bu nedenle sürekli ve düzenli bir iş bulamamakta, iş bulanlar da sigortasız olarak kayıt dışı çalışmakta ve gerek kira ödeyecek paraları olmadığı için ve gerekse polise yakalanma korkusuyla, depo, garaj, izbe pansiyonlar gibi, geçici, sağlıksız, kötü koşulların egemen olduğu yer ve mekanlarda yaşamakta, yakalanma tehlikesine karşı sürekli olarak yer değiştirmek zorunda kalmaktadırlar. Dolayısıyla yoksulluk ve polis baskısıyla pekiştirilmiş bir marjinalliği yaşayan bu kişiler için, dil, kültür, kimlik, aidiyet gibi durumlar yoksulluk, güvenlik, kaygı ve korku eşiğini aştıktan sonra yüzleşilmesi gereken ikinci dereceden sorunlar olarak görünmektedir. Oturma belgeleri olmadığı için, yasal bir işte çalışmaları olanaksız olan bu kişiler, uyuşturucu, seks ticareti gibi yasa dışı ve toplumun benimsemediği sömürü alanlarında çalışmakta, bu çözümsüzlük de marjinal durumlarını uç noktalara taşımakta, tehlikeli hale getirmektedir. Diğer yandan, kimi marjinal göçmenlerin çaresizliği gerek diğer çıkarcı göçmenler tarafından ve gerekse etkili ve yetkili Fransızlar tarafından kötüye kullanılmakta ve onların trajedisinden beslenen çıkar çıkar elde etmeye, toplumsal ve parasal güç sahibi olmaya çalışmaktadırlar. Leyla'nın, Huriye'nin, Simone'nun, Nono'nun yaşadıkları sorunlar kültür, kimlik ve aidiyet sorunu olmaktan öte daha yaşamsal sorunlardır. Zira Leyla ve Huriye Fransa'ya gelmeden daha kendi ülkelerindeyken, taciz, şiddet, açlık, kötüye kullanma... vb. sorunlarla karşı karşıya kalmışlardır. Ama elbette göçmen olmaları ve oturma belgesine sahip olmayışları ve etnik kökenleri de karşılaştıkları sorunlarda hem belirleyici olmakta, hem de bu sorunların çözümünü güçleştirmektedir. Ama Le Clézio'da ulusal, etnik, dinsel biçimleriyle aidiyet hiçbir zaman sadece kökensel değer ve göndergeleriyle ayırt edici olmamıştır. Tüm uygarlıklara, kültürlere eşit derecede yaklaşan ve hatta kayıp uygarlıklara ve ezilmiş, sömürülmüş uluslara özel bir sempati besleyen Le Clézio'da aidiyet, kişinin kendini arayışının önemli bir aşaması olan insanlık ailesi içinde yerini tanıması açısından önemlidir ancak. Bu nedenle, Le Clézio'nun bu romanında dünyanın her tarafından, Fas'tan, Kamerun'dan, Haiti'den, Senegal'den gelmiş bulunan, insanca var olabilmek için kendi varlıklarının dışında hiçbir şeye sahip olmayan göçmen marjinaller, varlıklarını insanca koşullar altında gerçekleştirememenin sıkıntısını, seks, alkol, uyuşturucu gibi bir takım aldatıcılara başvurarak gidermeye çalışırlar. Kimileri de müzik, spor gibi daha yaratıcı ve olumlu etkinliklerle ayakta kalma savaşı verirler. Burada Le Clézio'nun vurgulamaya çalıştığı 
şey, Onimus'un belirttiği gibi az gelişmiş ülkelerden batının sanki bir cennetmiş gibi algılanmasıdır. "Insanlar sınırlara akın eder, gizlice girerler. Ama bir defa içeri girdiklerinde, köle haline gelir, tutsaklaşırlar." (Onimus 1994: 95)

Fas'tan, Fransa'ya, Fransa'dan Amerika'ya dünyanın her yerinde Altın Balık’a gerilen ağlar, kurulan tuzaklar, giderek yaşamın amacını ve değerini maddesel beklenti ve çıkarlara indirgeyen, yasalarını işlevsel akıl ve üretim-tüketim alışkanlıklarının belirlediği batı uygarlığının değerlerini simgesel ya da açık bir biçimde tartışmaya açmaktadır. Romanın marjinal karakterlerinin her biri batının iki yüzlülüğünü yüzüne vuran gizli bir gözlemci gibidir. Leyla daha Fas'tayken biri Fransız biri alman olmak üzere iki üst düzey Avrupalı tarafından taciz edilir. Fransa'ya geldiğinde yardım edeceğine ilişkin söz vererek onu evine alan bir kadın doktorun, Doktor Fromaigeat'ın; cinsel tacizine uğrar, (Le Clézio 1997: 97) bir kez de sokakta tanımadığı bir sokak serserisinin cinsel eyleminin kurbanı olur (Le Clézio 1997: 47) ve bu tür tecavüz girişimi ve saldırılardan korunmak için çıkarılması zor olan dar kot pantolonlarla dolaşmaya başlar.

Haitili bir kadın Simone da bu romanda dikkat çeken bir diğer marjinal karakterdir. Müzik alanında oldukça yetenekli, genç ve güzel bir kadın olan Simone, doktor olan Fransız sevgilisi ona şiddet uyguladığı halde bir türlü ondan kurtulamaz zira sevgilisi onu uyuşturucuya alıştırmıştır. Leyla gibi kim olduğunu bilmeyen Simone'nun ona söylediği şu sözler marjinalliğini ve bunun doğurduğu çaresizliği vurgulaması açısından ilginçtir: "Sen de benim gibisin. Kim olduğumuzu bilmiyoruz. Bedenlerimiz artık bizimle değil" (Le Clézio 1997:119) Daha sonra Leyla'nın dile getirdiği şu tümceler içinde bulundukları trajik durumu pekiştirir niteliktedir: “....birdenbire niçin onun birbirimize benzediğini söylediğini anladım, ikimizin de bedeni yoktu, çünkü hiçbir zaman hiçbir şey istememiştik ve her zaman başkaları bizim yazgımıza karar vermişti." (Le Clézio 1997:123) Göçmenlerin, düşmüş, itibarsızlaştırılmış insanların, çaresizliklerinden, zayıflıklarından yararlanan diğer açgözlü Avrupalılar gibi Simone'un sevgilisi de genç kadını kendine bağımlı kılmak için onu uyuşturucuya alıştırmıştır. (Le Clézio, 1997: 131). Bu nedenle Simone onu terk etmek istese de terk edemez. Kendisini aldattığı gerekçesiyle genç kadına şiddet uygulayan sevgilisi bir arkadaşıyla birlikte ona tecavüz etmeye yeltenir (Le Clézio 1997: 130). Simone modern dünyanın vampirlerinin kanını emdikleri bir karakter olarak romanda önemli simgesel bir yer tutar. Kendisi iri gözleriyle, siyah mermer gibi parlayan çıkık alnıyla mısır tanrıçaları kadar güzeldir ama beyaz Avrupalının arzularının aracı olmuş durumdadır. Burada Le Clézio, hırsız olarak nitelediği Avrupa'nın (Le Clézio 1969: 255) insanlığın beşiği olan Afrika'nın yer altı zenginliklerini, kültürünü çaldığı gibi, kutsal değerlerini de çiğnemiş, onlara saygısızlık etmiş, itibarsızlaştırmış olduğunu vurgular. Le Clézio, işgalci sömürgeciliğin tarihsel ve kuramsal olarak sona ermiş olmasına karşın pratikte devam ettiğinin altını çizmektedir. Batı kapitalizminin temsilcisi sömürgeci ülkelerin, sömürdükleri ülkelerin ekonomilerini kendilerine bağımlı hale getirmelerine bağlı sömürgeciliğin de devam edeceğine de vurgu yapmaktadır. Simone her ne kadar Haitili olsa da kadın olarak üzerinde topladığı, kutsallık, maneviyat gibi değerler bakımından, tüm sömürülen, kültürleri, maddi ve manevi zenginlikleri çalınan tüm ülkelerin kadınını simgelemekte ve yaşadığı aşağılanmışlık, taciz, şiddet ve karşılaştığı diğer insanlık dışı davranışlarla da, batının, sömürdüğü toprakların kutsalını, maneviyatını değersizleştirdiğine işaret etmektedir. Simone'nun tüm yaşadıklarını unutmak için sığındığı müzik bir kaçış olmasının yanı 
sıra evrensel birleştirici bir dili işaret etmesi açısından da Le Clézio tarafından ustalıkla kullanılmıştır. Simone'un yaşadıklarını unutmak için bir yandan uyuşturucuya, diğer yandan müziğe sığınması çelişkili gibi görünmekle birlikte, marjinal karakterin parçalanmışıı̆ına vurgu yapması açısından özellikle dikkat çekicidir. Müzik, Haitili bir zenci olan Simone'un yeteneğini ve dolayısıyla sömürülenle ilgili bir değeri simgelerken, sevgilisinin bağımlı hale getirdiği uyuşturucu da sömürünün simgesi olmaktadır. Bu karşıtıık başkarakter Leyla'da farklı bir biçimde ortaya çıkar. Olağanüstü bir entelektüel yeteneğe sahip olan ve bu alanda kendinden beklenemeyecek bir başarı elde eden Leyla, modern dünyanın kendine gerdiği ağlara, kurduğu tuzaklara karşı öfkesini çalarak göstermektedir. Leyla'nın marjinal olma halinin bir davranış biçimi olarak ortaya çıkan çalma eylemi tersinlemeli olarak, çalan, sömüren, yıkan, yok eden, değersizleştiren batı dünyasının yarattığı yangın karşısında küçük ve etkisiz bir öfke kıvılcımı olarak değerlendirilebilir. Zira Batı'nın sömürü ile elde ettiği güç o denli büyük ve etkili olmuştur ki az önce de bahsettiğimiz gibi bu güçle kurduğu kapitalist sistemle sömürüsünü sistemli ve örgütlü bir hale getirmiş ve dolayısıyla da yarattığı yıkım ve yangın Le Clézio'nun "sürekli savaş" adını verdiği önüne geçilemez bir "insanlık durumu"na. dönüşmüştür.

Romanda dikkat çekici marjinal karakterlerden bir diğeri Kamerunlu Nono'dur. Nono için Fransa'da ayakta kalmanın yolu dövüşçü olarak başarıya ulaşmaktır. Bu alanda başarılı olarak Fransız hükümetinden oturma izni almanın hayalini kurmaktadır. "Tanıdığı sosyalist bir milletvekili maçı kazanması durumunda kendisine oturma izni alacağına söz verme" (Le Clézio 1997: 125) sine rağmen oturma izni alamayan, zira maçı kaybeden Nono'nun durumu tam anlamıyla bir güç sömürüsünü işaret etmektedir. Diğer yandan, Le Clézio, bu sosyalist milletvekili üzerinden, görüntüde mağdurların, ezilmişlerin yanındaymış gibi görünen ama pratikte onların durumlarını düzeltmek için hiçbir girişimde bulunmayan rahatı yerinde zengin politikacıları, aydınları ve entelektüelleri de eleştirmekte ve böylece bir başka açıdan batı dünyasının ikiyüzlülüğünü ortaya dökmektedir. Bu bakımdan Nono karakterinin, romana figüratif bir çeşni katmak üzere kurgulanmadığı açıktır. Le Clézio burada güç sömürüsüne dayalı köleciliğe simgesel bir gönderme yapmaktadır. Nono'nun güce dayalı bir spor olan boksla ilgilenmesi ve fiziksel özellikleri sömürgeci batının tarihin bir döneminde kurumsallaştırdığı hem insan bedenine eziyeti hem bu bedenin aşağılanmasını, sıradan bir araca, hatta hayvan konumuna indirgenmesini onaylayan, bir başka sömürü biçiminin, köleliğin, sembolik uzantısını akla getirmektedir. Milletvekili boksör Nono'nun fiziksel gücünden maddi çıkar elde etme düşüncesindedir ve maçı kazandığı takdirde ona oturma izni alacağı sözünü vermiştir. Nono maçı kazanamamıştır ama kazanmış olsaydı bile oturma izni alması kesin değildir. Zira milletvekilinin amacı Nono'ya oturma izni almak değil onu sömürmektir. Zira Farntz Fanon'un da belirttiği gibi "Zenci biyolojik olanı temsil eder...sıcak kanlıdırlar, güçlü kuvvetli, enerji idolü insanlardır” (Fanon 2016: 201). Kamerunlu bir zenci Nono da sağlam, iri yapılı bedensel özellikleriyle, biyolojik yanıyla (çoğu zaman bir yayvan gibi yarı çıplak ya da çıplak olarak antrenman yapar) bir beyazın gözünde tam da fiziksel olarak sömürülecek, gücünden, kuvvetinden yararlanılacak biridir. Nono hem yapısal/fiziksel özellikleriyle hem de diğer yönleriyle tam bir zenci heykeli olarak canlanır gözümüzde. Ama ne yazık ki diğer marjinal karakterler gibi Nono'nun da, kendisi gibi insanları tutsaklaştıran, tüm gücünü, enerjisini soğuran bu umarsızlık, yoksunluk, yoksulluk labirentinden çıkmasına imkan yoktur ve o 
eşitsizliği, adaletsizliği besleyen, tırmandıran aşırı çıkarcı, bireyci, maddiyatçı toplumsal sistemin kurbanı olur.

Le Clézio'nun romanlarında tartışmaya açtığı konulardan biri de aşırı derecede teknokratik tüketim toplumudur. Üretim ve tüketimin kutsallaştırıldığı ve insan ilişkilerinin bu iki eylem üzerinden kodlandığı böyle bir toplumda insanın kendi olabilmesi gibi türdeşiyle sağlıklı ilişkiler kurması da oldukça zor görünmektedir. Bu yönüyle insanların yığınlar halinde yaşadıkları kentler de, yüksek binalarıyla, hipermarketleriyle, "avm"leriyle, kenti ve insan yaşamını baştan sona kuşatan teknolojik örgüsüyle renkli modern "vahşi orman"lar olarak betimlenir. Aşırı tüketim toplumuna ilişkin en belirgin etkenliklerden biri de ürettiği çöptür. Dünya sadece üretilen ve tüketilen bir yer olarak, işlevsel boyutuyla algılanıp yorumlandığında da sonuçta üretim ve tüketim etkinliğinin çöplüğü haline geliyor. Romanda çingene bir çocuk olan Juanico adlı marjinal karakter aracılığı ile Le Clézio bir kez daha dünyayı tüketim etkinliğinin çöplüğü haline getiren, tüketimi kutsallaştıran kapitalist dünya düzenini sorgular. Dayısı çöp ayrıştırıcılığı yapan Juanico ile Nice kadar giden Leyla, bu kentin kenar mahallelerinde çöp dağları arasında kaybolmuş toplu konutlarda yaşayan yoksul insanların yaşamlarına, hayat mücadelelerine, kavgalarına tanıklık eder. Dikkat çekilen nokta yalnızca tüketim toplumunun ürettiği çöpler değil bu çöpleri iş alanı olarak seçmiş olan insanların ileri marjinalliği, yoksulluğudur. Bu yoksulluğa rağmen başta Juanico ve diğer çocuklar olmak üzere bu insanların canlı, neşeli, hayat dolu ama aynı zamanda kavgacı olmaları anlamlıdır. Le Clézio'unun özellikle ikinci dönem (Çöl adlı romanı ile başlayan1980'den sonrası) yapıtlarının çocuk karakterlerinin hemen hemen hepsi yaşama bağlı, son derece canlı, neşeli karakterlerdir. Bu da onların doğa ile dış dünya ile kurdukları ilişki ile ilgili gözükmektedir. Mutluluğu maddesel sahiplikte değil doğa ile kurdukları ilişkide aramaları ile ilişkilidir. Dış dünya ile, doğa ile ilişki içinde olma, canlıık, neşe karşılaşılan zorluklara, yaşanan mutsuz deneyimlere, yoksulluğa karşın yaşama bağlı olma, Le Clézio'nun marjinal karakterlerinin olduğu kadar, diğer karakterlerinin de en belirgin özelliğidir. Bir çoğunun evi ve ailesi olmayan bu marjinal karakterler günlerinin büyük bir kısmını dışarıda geçirir, toprakla, denizle, güneşle, rüzgarla, doğa ile dış dünya ile olabildiğince fazla ilişki içinde olmaya özen gösterirler. Bu biçimde Le Clézio, kentlerin mutsuzluk veren ortamına kapatılmış, tüketerek mutlu olmaya çalışan kent insanının karşısına, doğa ile kurduğu ilişki ile mutlu olmayı seçen insanları çıkarır. Marjinal, dünyayı canlı kılan gücü dile getirme, yorumlama yolunu gösterir. Inconnu sur la Terre adlı kitabındaki şu tümceler bu açıdan oldukça anlamlıdır: "Vadinin üzerindeki fırtınayı seyrediyor, sinemanın, tiyatronun, müziğin bana hiçbir zaman veremeyeceği şeyi içimde hissediyorum. Hiçbir insan yaratısı hiçbir şeyi bu kadar tutkuyla, bu kadar güçlü, bu kadar ayrıntılı bir biçimde dile getiremez." (Le Clézio 1978: 113) Kentlerde varsılın yarattığı çöplüğün yoksulun iş alanına dönüşmesini de ironik bir vurgu olarak yansıtan Le Clézio aslında marjinal karakterleri aracılığıyla yaşam bilgeliğini nerede aramamız gerektiğini gösterir.

Le Clézio Le livre des fuites adlı yapıtında Batı dünyasını hırsızlıkla suçlar ve bu savını şu tümcelerle dile getirir: "Beyaz adam herkesten her şeyi çaldı... Yahudilerden dini, Araplardan bilimi, Hindulardan edebiyatı çaldı. Zencilerin bedenlerini çalmayı bitirince de onların müziğini, dansını, sanatını çaldı." (Le Clézio 1969: 255) Altın Balıkın özgün bir karakteri olarak romanda oldukça özellikli bir yere sahip olan Senegalli Hakim bu açıdan bir anlamda Le Clézio'nun sözcüsü olur. Paris'te üniversite 
eğitimi gören ve dedesi Fransız ordusunda işgalcilere karşı savaştığı için Fransa'da oturma iznine sahip tek zenci olan Hakim çevresindekilere yabancılaşmadan, Frantz Fanon'dan, Aimé Césaire'den, beyazların sömürüsünden, etnik ayrımcılıktan bilinçli olarak ilk söz eden karakter olarak da dikkat çeker:

" Hakim ince uzundu ve siyah kostümüyle hep şıktı. Tuhaf şeyler anlatıyordu. Bir gün bana eski bir kitap getirdi, elden ele dolaşmış ve yıpranmış bir kitaptı. Adı Les Damnés de la terre'di ve yazarı Frantz Fanon'du...Hakim Nono'yu sevmiyordu...Boksörlük mesleğine hiç saygı duymuyordu, onun yabancılaştığını, beyazların, uşağı, oyuncağı olduğunu ve bir yeri kırılır kırımaz beyazların onu çöpe atacağını söylüyordu..."Yabancılaşmanın ne demek olduğunu biliyor musun?" diye başlıyordu." (Le Clézio 1997: 108)

Sömürge, sömürgecilik, Batı'nın, beyaz adamın ikiyüzlülüğü konusunda bilinçli bir genç olan Hakim'in varlığı Fanon'un, Césaire'in düşüncelerinin de romanda yer bulmasına olanak sağlar. Hakim'in dedesi El Hadj, Fanon'un düşünceleri konusunda şunları söyler:

"Fanon'u çok doğru şeyler de söyler. Zenginlerin yoksulların iliğini sömürdüğü doğru. Fransızlar memleketimize gelince, genç erkeklerimizi tarlalarda çalıştırmak, genç kızlarımızı da masalarında hizmet ettirmek, yemek yaptırmak ve onlarla yatmak için elimizden aldılar, çünkü karılarını Fransa'da bırakmışlardı." (Le Clézio 1997:112)

Aimé Césaire' in "Danslarım bana aittir/ kötü zenci danslarım/ danslarım bana aittir/ demir halkalar takarak yaptığım dansım/ mapusaneden kaçış dansım/ dans etmek zenci olmak güzeldir-iyidir-yasaldır."(Le Clézio 1997:120) dizeleri de "négritude"6 kavramında ifadesini bulan onaylanan ya da onaylanmayan yanlarıyla, olumlu ya da olumsuz nitelikleriyle zenci olmayı olumlamaya çağııı. "Barbar Batı" hakkında söyledikleri bu yazının başından beri belirttiğimiz gibi, Le Clézio'nun Batı Dünyası hakkında söyledikleri, düşündükleri ile büyük bir benzerlik oluşturan Aimé Césaire “ Burjuva Avrupa bundan başka ne yaptı?" diye sorar ve yine kendisi yanıtlar:

Medeniyetlerin kökünü kazıdı, ülkeleri ortadan kaldırdı, milletleri harabetti, "farııı̆ın kökünü" kazıdı. Artık daha fazla set daha fazla siper kalamadı. Barbarın zamanı yakındır. Modern barbarın. Yani Amerika'nın zamanı. Şiddet, ifrada vardırma, israf, savurganlık, merkantilizm, blöf, konformizm, aptallık bayağılık, kargaşa. (Césaire 2007: 117)

"Onlar öldürdüler; onlar yağmaladılar..." (Césaire 2007: 65) biçiminde sömürgeci ruhun en tipik iki eylemine vurgu yapan Aimé Césaire'in yağmalamak olarak belirttiği eylemi en geniş anlamıyla düşünmemiz gerektiğini tarihsel tanıklık ve belgeler tanıtlayabilir ama Hakim'in, Paris'teki Afrika sanatları Müzesi'inde heyecanını yenemeyerek şu söyledikleri batının yağmalamasının korkunç boyutlarını gösterir niteliktedir:

\footnotetext{
6 Aimé Césaire'in Discours sur le colonialisme adlı yapıtında ifadesini bulan ve siyahların kenilerine ait manevi, kültürel değerleri olumlu ya da olumsuz taraflarıyla benimsemelerini, olumlamalarını dile getiren ve bu kültüre ait olmaktan gurur duyulması gerektiğini vurgulayan yaklaşımına verilen ad.
} 
Şu maskelere bir bak...Bak Leyla her şeyi kopya ettiler, her şeyi çaldılar. Heykelleri, maskeleri çaldılar ve ruhları da çaldılar... Hepsi birer mahkûm ve dile gelemiyorlar. Oldukları yerden koparılıp alınmışlar. Ama öbür yandan da, dünyada varolan her şeyin kökeninde onlar var... Hepsi çok eski zamanlarda kök salmışlar, buradaki insanlar, terden siyahlaşmış yüzleri ve yoksulluktan çürüyen dişleriyle yeraltındaki deliklerde yaşarken, onlar vardılar... Bak Leyla: oralardan gelen en ufak bir nesne bile hazine ya da inci değerindedir... Bunlar bizim kemiğimiz ve dişimiz, görüyor musun, bunlar vücudumuzun parçaları, derimizle aynı renkteler, ateş böcekleri gibi geceyi aydınlatıyorlar...Gördün değil mi? Bir şey çalmamam için gözetliyordu beni. Atalarımın kemiklerini çalıp kaçmamam için.(Le Clézio 1997: 108,109,110)

Romanı bir anlamda batı sömürgeciliğini sorgulayan bir düzleme oturtan Hakim karakteri romana ayrıca düşünsel bir boyut katar ve eleştirel boyutunu da doruk noktasına taşır ama Le Clézio'nun başarısızığa uğramış bu marjinal karakterleri içinde hiç değilse Hakim'in başarılı olacağı konusunda umut uyandıran göstergelere karşın o da başarılı olamaz zira eğitimi için ayırdığı parayı Fransa'da ölen dedesinin cenazesini, gömülmeyi istediği memleketine götürmek için harcamak zorunda kalır.

Yoksulluk kaynaklı ilerileri marjinalliğin yaşandığı kenar mahalleler, gettolar ve kentin merkezinden uzak periferide oluşan marjinal mekanlardan ayrı olarak, merkezden uzakta olmayan ya da derinliğine merkezi ıraksayan mekanlardan söz etmek mümkündür. Bu açıdan Altın Balık'ta marjinal karakterlerin yaşadıkları mekanların marjinalliğinden söz edilebilir. Sağlıksız, konforsuz, bakımsız ve görece temiz olmayışlarıyla dikkat çeken bu mekanlar marjinalliğin uzamsal boyutunu oluştururlar. Bu mekanların en belirgin özellikleri, sürekli olmamaları, polise yakalanma korkusu yaşayan marjinallerin gelip geçici sığınakları olarak karşımıza çıkmalarıdır. Ev değil, ocak değil, yuva hiç değil. Geçici olarak sığınılacak bir yer, dört duvar. Çoğu zaman gözden uzakta, polisin ulaşamayacağı konumda olan bu mekânlar marjinallerin yaşadığı değil, yok oldukları yerlerdir. "...haşarat gibi toprağın altında saklanıyorduk" (Le Clézio 1997:106) diyen Leyla'nın acı bir toplumsal eleştiri niteliğindeki bu sözleri marjinal mekanların olduğu gibi marjinallerin durumunu da açık bir biçimde gözler önüne sermektedir. Nono'nun kaldığı ve daha sonra, Leyla ve Huriye'nin de kullandığı, bir süre sonra sevgilisinin şiddetinden kaçan Simone'nun da sığındığı bu mekân garajdan bozma bir yerdir:

Nono'nun yer altında kaldığı yer küçüktü, hiç ışık yoktu...Burası bir daire değil, bir garaj ya da bodrum katıydı...Kapılar üzeri çiziklerle dolu ağır demirden, tavanlar kocaman tonozlardan yapılmıştı ve garaj beton hücrelere bölünmüştü. Fakat bu işe yarıyordu, çünkü gürültü böylece gelmiyordu, sadece zaman zaman bir kanalizasyondan gelen glu glu sesi ya da vantilatörün sesi işitiliyordu. (Le Clézio 1997: 100,101)

Yeterince ışık almayan bu mekân aynı zamanda havalandırma açısından da yetersiz, normal koşullarda içinde sağlıklı bir yaşam sürdürmenin olanaksız olduğu, ancak zorunlu durumlarda sığınılabilecek bir yerdir. Huriye'nin çocuğunu burada doğurmak zorunda kalması marjinallerin içinde bulundukları koşulları, karşılaştıkları zorlukları, yaşadıkları çaresizliği açık bir biçimde gözler önüne serer. Bu mekânlar kayıt dışı varlıkların, ölümle burun buruna hayatların sürüklendiği yerlerdir. Yaşamak için değil, sokakta kalmamak için sığınılan ama farkında olmadan ölünen yerlerdir. 
Huriye'nin bebeğini doğurduktan sonra bu yere hakim olan ter ve idrar kokusu, karanlık ortamı yaşamdan çok, ölüme özgü bir yer olduğunu düşündürür: "Odanın içi sidik ve ter kokuyordu, biraz acı bir koku. Bir yerlerde pencere olsaydı, temiz hava ve güneşin girmesi için iyice açacaktım. Bebeğin buradan çarçabuk çıkarılması gerektiğini düşündüm, aksi halde yerin altında ölür kalırdı." (Le Clézio 1997: 127) Leyla bu doğumdan söz ederken "Şubat ayında, Huriye'nin bebeği doğdu. Bebek doğunca, belki ilk kez bir çocuğun yerin altında doğmuş olduğunu düşündüm; gün ışığından öylesine uzakta, derin bir mağaranın dibinde doğmuş gibi" ( Le Clézio 1997: 124) derken de sanki yeraltı tanrısına, Hades'e sunulmuş bir yaşamdan bahsediyor gibidir. Böylece yeraltında doğumun aslında ölüme doğum olduğunun da altını çiziyor görünmektedir. Zira gün ışığından uzakta doğmuş olan bir çocuğun kaderi zaten bellidir; gün yüzü görmemek, sözcüğün hem gerçek hem de dilimizdeki mecazi anlamıyla.

\section{Sonuç}

Yazma eylemini "sismograf"ın yaptığı işe benzeten Le Clézio, yazarın, yaşamın, dünyanın, doğanın titreşimlerini yetkinliği içinde kaydedebilmek için yalnızca sözcüklere yetinmemesi gerektiğini zira yazmanın sadece söylemek olmadığını bunun yanında daha derin sarsıntı, ürperiş ve kımıltıları dile getirmek olduğunu belirtir. Bu bakımdan Le Clézio'nun romanlarında özenle seçilmiş, belli bir özelliklerle donatılmış, yazınsal örgünün içinde ustalıkla betimlenmiş karakterler çok önemlidir. Bir karakterin varlığı kimi zaman tek başına sözcüklerin söyleyeceğinden daha fazla şey anlatır. Le Clézio'nun Altın Balık adlı romanının marjinal karakterleri de bu açıdan yazarın söylemek istediklerini sadece varlıklarıyla ve marjinal olma durumlarıyla açığa vuran, ortaya çıkaran bilinçlerdir. Bu marjinal karakterlerin kimileri bizi var olmanın acı bilgisine ulaştırırken, kimileri yaşamın, dünyanın çatlaklarını, kırıklarını, yıkıntılarını gözler önüne serer, kimileri toplumsal çürümeyi, yaşamın kokuşmuşluğunu yansıtırlarken kimileri de toplumun kara deliklerini gösterir. Le Clézio bu marjinal karakterler üzerinden batı toplumunun çıkmazlarını, kapitalist sistemin yarattığı evrensel ölçekli sorunları gündeme taşır, yoksulluğu, başta ekonomik, cinsel olmak üzere her türden sömürüyü, dünyayı yüksek kazanç çıktısının yarattığı bir yoğaltım çöplüğü haline getiren ve bu biçimde doğayı da yok olma tehlikesi ile karşı karşıya bırakan aşırı teknokratik tüketim toplumunu sorgular, sorgulatır. Yaşamın özünü maddesel beklenti ve çıkarlara indirgeyen, yasalarını işlevsel akı, üretim ve tüketim alışkanlıklarının belirlediği Batı Uygarlığ'ının değerlerini tartışmaya açar. Bu karakterlerin her biri toplumsal bir sorunu kaydeden, irdeleten birer bakış olarak karşımıza çıkar ve modernitenin, Batı Uygarlı̆̆ı'nın temellerini de sorgulatır. Bu marjinal karakterler, ayrıca Batı'nın doğrusal ilerleme ve rasyonel düşünme inancının nasıl bozguna uğradığına da tanıklık ederler ${ }^{7}$

\section{KAYNAKLAR}

BAREL, Yves (1982), La Marginalité sociale, Paris: Presse Universitaire de France.

\footnotetext{
${ }^{7}$ Chambers lain, Göç, Kültür, Kimlik Çevirenler: İsmail Türkmen \& Beşikçi, Ayrıntı, 2005, İstanbul. Arka kapak yazısından alıntılanmıştır.
} 
BOULOS, Miriam Stendal (1999), Chemins pour une approche poétique du monde: Le roman selon J.M. G. Le Clézio, Copenhague: Museum Tusculanum Press.

CESAIRE, Aimé (1955), Discours sur le colonialisme, Paris: Éditions Présence Africaine.

CESAIRE, Aimé, (2007), Barbar Batı, (Çeviren. Güneş Ayas), İstanbul: Salyangoz Yayınları

CHAMBERS, Iain (1994), Göç, kültür, kimlik, (Çeviren: İsmail Türkmen\&Mehmet Beşikçi, İstanbul: Ayrıntı.

COLLINS, Randall ve MAKOXSKY, Michael (2014), Toplumun Keşfi, (Çeviri editörü: Prf. Dr. Nurgün Oktik), Ankara: Nobel.

CUCHE, Denys, (2009), "« L'homme marginal »: une tradition conceptuelle à revisiter pour penser l'individu en diaspora", Revue européenne des migrations internationales, Vol. 25, no 3 p.13-31

FANON, Frantz, (2026), Siyah Deri Beyaz Maskeler, (Çeviren: Cahit Koytak), İstanbul, Encore Yayınları.

GOFFMAN, Erving, (2014), Damga, (Türkçe Söyleyenler: Ş. Geniş-L.Ünsaldı-S.N. Ağırnaslı ), Ankara: Heretik.

LE CLEZIO, J.M.G., (1969), Le livre des fuites, Paris: Gallimard.

LE CLEZIO, J.M.G., (1969, Inconnu sur la Terre, Paris: Gallimard.

LE CLEZIO, J.M.G., (1997), Altın Balık, (Çeviren: Bahadır Gülmez), İstanbul, İletişim.

ONIMUS, Jean (1994), Pour lire Le Clézio, Paris: Presse Universitaire de France.

ROBERT, Paul, (1983), Le Petit Robert 1 (Rédaction dirigée par A.Rey et J.ReyDebove), Paris: Le Robert.

WACQUANT, Loïc, (2014), Kent Paryaları (Çeviren: Mehmet Doğan), İstanbul: Boğaziçi Üniversitesi Yayınevi.

GENELAĞDAN ULAŞILAN KAYNAKLAR:

RIOUX, Liliane, (1998), Les dimensions spatiale et culturelle de la marginalité : une approchepsychosociologique.(http://horizon.documentation.ird.fr/exldoc/pleins_textes/d ivers4/010017379.pdf adlı internet adresinden 12.01.2020tarihinde ulaşımıştır.)

BOULOUMIE, Arlette (2003) Figures du marginal dans la littérature française et francophone, Angers: Presses universitaries de Rennes. (12.01.2020 tarihinde https://books.openedition.org/pur/28108 adlı internet adresinden ulaşılmıştır.) 